\title{
Evaluation of Solar Energy for Processing Aloe Secundiflora Sap into Paste Using Parabolic Solar Concentrating Technology
}

\author{
Mary Nelima Ondiaka ${ }^{\mathrm{a}}$, Wilber Lwande ${ }^{\mathrm{a}}{ }_{*}$, Emma Omulokoli $^{\mathrm{b}}$, John Bwire Ochola $^{\mathrm{a}}$, \\ Evelyn Alison Ndenga ${ }^{a}$, Maxwell Lumbasi Kilwake ${ }^{\mathrm{a}}$, Isabella Nyamoita Nyamamba ${ }^{\mathrm{a}}$, \\ Kavaka Mukonyi Watai ${ }^{\mathrm{c}}$, John Salehe ${ }^{\mathrm{d}}$, Elias Kimaru ${ }^{\mathrm{d}}$ and Thomas F.N. Thoruwa ${ }^{\mathrm{e}}$ \\ ${ }^{a}$ International Center of Insect Physiology and Ecology (ICIPE), P.O. Box 30772-00100, Nairobi, Kenya \\ ${ }^{b}$ Faculty of Science, Department of Chemistry, Jomo Kenyatta University of Agriculture and Technology (JKUAT), \\ off Nairobi-Thika Highway, Juja, Kenya. \\ ${ }^{c}$ Kenya Wildlife Service (KWS), Langata Road, Nairobi, Kenya \\ ${ }^{d}$ World Wide Fund for Nature-Eastern and Southern Africa Regional Programme Office (WWF-ESARPO), ACS Plaza, \\ Lenana Road No. 1/1203, Nairobi, Kenya \\ ${ }^{e}$ School of Engineering and Technology, Department of Energy Engineering, Kenyatta University, off Nairobi-Thika \\ Highway, Nairobi, Kenya
}

\begin{abstract}
This paper presents an alternative method of processing Aloe secundiflora sap into paste using solar concentrating technology. Local communities living in arid and semi-arid areas of Kenya and other African countries harvest $A$. secundiflora sap and process it into paste for export and local use by boiling using traditional 3-stone cooking stoves. Consequences of these activities have led to widespread deforestation and environmental degradation. The study focused on establishing the effectiveness of solar concentrating technology in processing A. secundiflora sap into paste and ascertaining the effect of environmental parameters on processing. Optimum processing temperature, processing time, cooker efficiency, yield and quality of the resultant paste were also investigated. Results showed that absorber and pot content temperatures and solar radiation significantly affected the heating time. It was established that optimum processing temperature ranged from $90-100^{\circ} \mathrm{C}$, giving an average overall heat transfer coefficient of $17.40 \mathrm{~W} / \mathrm{m}^{2} \mathrm{~K}$ under clear sky conditions. Results demonstrated that solar concentrating technology had great potential in processing A. secundiflora sap into paste, which is a stable, portable and value added product. In the longer term, using solar energy to substitute fuelwood energy would contribute to reduced deforestation, environmental degradation, global warming and climate change. It would also improve biodiversity conservation and reduce the burden on women and children associated with collecting and transporting fuelwood. As a follow-up to this study, an elliptical parabolic solar concentrator was installed at Kinango in the semi-arid Kinango District, Coast Province of Kenya for pilot-scale processing of A. secundiflora sap by a local women group.
\end{abstract}

Keywords: Energy, Solar parabolic concentrators, Aloe secundiflora, Fuelwood, Processing paste, Environmental degradation.

\section{INTRODUCTION}

A. secundiflora Engl. (Family: Asphodelaceae) is a succulent, perennial herb that is distributed in dry, semi-arid, sandy grassland and open woodland regions in Rwanda, southern Ethiopia, Kenya and Tanzania [1-3]. It is one of about 450 species of the genus Aloe that occur in Africa and Arabia [1-3]. A. secundiflora is easy to propagate usually from seed [1].

Traditionally, A. secundiflora has been used by local communities for the treatment of a range of human and

*Address correspondence to this author at the International Center of Insect Physiology and Ecology (ICIPE), P.O. Box 30772-00100, Nairobi, Kenya; Tel: +254 020 8632040; Fax: +254 020 8632001/2;

E-mail:wlwande@icipe.org livestock diseases, and for fermentation of local beer [1, 4]. In East Africa, particularly in Kenya, A. secundiflora plants are commercially exploited by local community members in dry, semi-arid regions who cut the leaves at the base [See: Fig. (1)] and drain a yellow bitter sap that exudes from the leaves and is collected in containers. The sap is sold to local dealers who process it by cooking in drums mounted on the traditional 3-stone fuelwood cooking stoves [See: Fig. (2)] until it forms a paste. On cooling, the paste hardens into a rocky dark green paste $[1,5]$. Unlike the A. secundiflora leaf sap, the rocky paste is less bulky, less perishable, more stable and therefore easier to handle, store, use and trade in. The dealers sell the A. secundiflora rocky paste to traders who export most of it to overseas countries [1,5]. The paste is used in the manufacture of pharmaceutical and cosmetic products including crude medicine for stomach pains and bathing soaps, while some is used by alcoholic beverage 


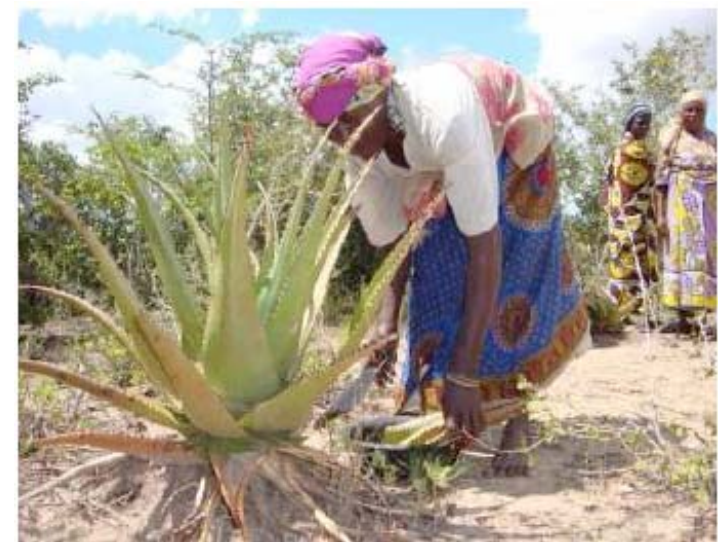

Fig. (1). Harvesting A. secundiflora in Kinango, Kinango District, Kenya.

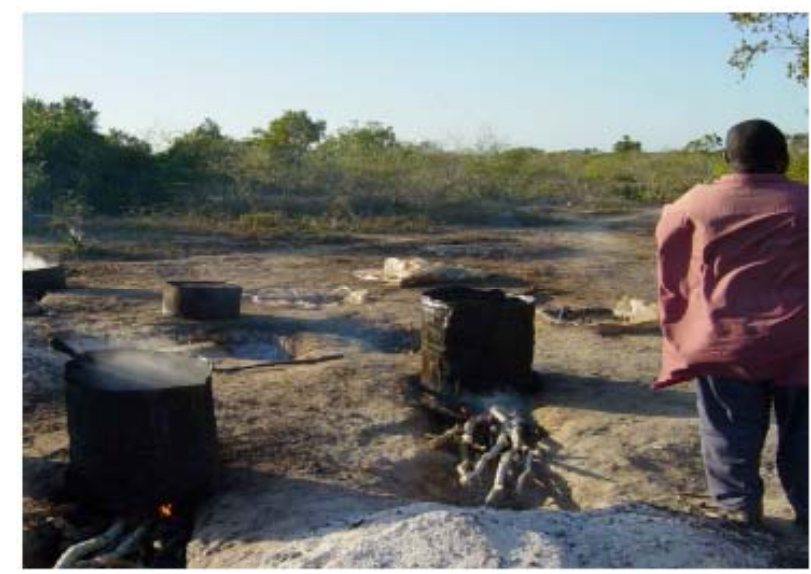

Fig. (2). Processing A. secundiflora into paste using fuel wood energy in Kinango, Kinango District, Kenya.

companies to produce bitters $[1,5]$. Local communities use small quantities of the paste to produce medicinal and cosmetic products such as soap, creams and shampoos for sale in the rural local market.

Previous research findings have revealed that extracts from A. secundiflora are efficacious against Salmonella gallinarum in experimentally infected free-range chickens [6] and have antiviral activity against the Newcastle disease virus (NDV) in embryonated specific pathogen free (SPF) chicken eggs $[7,8]$. The results have provided scientific justification for the ethnoveterinary use of A. secundiflora extract in the control of fowl typhoid and Newcastle disease virus in chickens. A crude extract of $A$. secundiflora leaves was found to inhibit the growth of the fungus, Candida albicans [9]. A preliminary phytochemical analysis of A. secundiflora exudate revealed that it comprised of a mixture of phenolic compounds, mainly the anthrones, aloenin, aloenin B, isobarbaloin, and barbaloin, and aloin derivatives, and chromones and phenylpyrones, with a low content of polysaccharides and aliphatic compounds [10]. A. secundiflora shrubs have also been shown to have facilitative effect on the establishment, growth, and reproduction of grass in degraded semi-arid rangelands where they could play a useful role in ecological restoration $[11,12]$.

A. secundiflora has been recognized to have a great potential in improving livelihoods of rural communities in dry, semi-arid areas of Africa [5, 13, 14]. A number of programmes are being undertaken and supported by institutions, organizations and donor agencies to promote communitybased cultivation and processing of A. secundiflora in dry, semi-arid regions in East Africa as an alternative incomegenerating activity for improved livelihoods of marginalized communities [5]. In Kenya, the Kenya Wildlife Service (KWS) has established regulations and developed a long term strategy for conservation, management and utilization of Aloe species in order to promote its sustainable exploitation by marginalized rural communities [15].

The major draw-back to the exploitation of $A$. secundiflora by local communities in dry, semi-arid regions of Africa is the unsustainable and environmentally destructive use of fuelwood for processing A. secundiflora leaf sap into paste. Most fuel wood used is collected mainly by women and children from the surrounding areas that are already experiencing serious deforestation, environmental degradation and biodiversity destruction, or purchased from local dealers. In the study, parabolic solar concentrating technology was evaluated for processing A. secundiflora sap into paste. Research on design and testing of solar parabolic cookers has been conducted [16-20]. The potential for solar energy in industrial process heating has been evaluated [21, 22]. The performance of a domestic solar parabolic cooker used for processing A. secundiflora sap into paste was introduced for the first time in the study.

The main goal of the research was to investigate the potential of solar concentrating technology to process $A$. secundiflora leaf sap into paste in comparison with conventional processing methods. The specific objective of the study were to: establish the efficiency of the solar parabolic cooker in processing $A$. secundiflora sap into good quality paste, compare the quality of $A$. secundiflora paste using solar concentrating technology against the traditional 3-stone fuelwood cooking stove and electric hot plate cooker and determine the carbon dioxide $\left(\mathrm{CO}_{2}\right)$ green house gas emission savings. It is expected that the research findings would form part of concerted efforts to identify environmentally safe and sustainable alternatives to replace fuelwood energy mainly used by communities in the dry semi-arid regions of East Africa to process the sap.

\section{MATERIALS AND METHODS}

The average yield, bulk density, gravimetric water content, specific heat capacity and Aloin A content of A. secundiflora leaf sap were determined. Traditional methods of processing A. secundiflora leaf sap into paste using fuelwood energy were assessed in the field. Comparative research studies were carried out using electric hot plate and solar parabolic cookers.

\subsection{Harvesting and Determination of Yield of $A$. Secundiflora Leaf Sap}

A. secundiflora leaf sap was obtained from Kinango location in Kinango District in the Coast Province of Kenya. A voucher specimen number SH2008: 2000 is deposited in the herbarium of the National Museums of Kenya. The sap was obtained in-situ from transverse sections of A. secundiflora leaves. Mature leaves of the plants were harvested from three 
different sites within Kinango District. During harvesting, the leaves were brushed to remove dust particles and cut at the base of the plants. A maximum of three leaves were cut from every plant and arranged at an angle around the edge of a stainless steel container measuring $50 \mathrm{~cm}$ wide and $15 \mathrm{~cm}$ deep and left for 30 minutes to allow the sap to drain into the container. The sap was filtered, transferred to glass jars and kept at $4{ }^{\circ} \mathrm{C}$ to preserve biological activity and reduce microbial count in the sap $[23,24]$. It was transported to Nairobi, Kenya where it was stored at $4{ }^{\circ} \mathrm{C}$. The A. secundiflora sap was stored for a maximum period of 14 days.

\subsection{Characterization of $A$. Secundiflora Leaf Sap}

Twenty litres of A. secundiflora leaf sap was stored at room temperature overnight. The sap was manually mixed to achieve homogeneity and its temperature measured and recorded. Bulk density of the sap was determined using modified ASTM D1895B standard [25]. One-litre of the sap was poured into a graduated cylinder and weighed to the nearest 0.1g using a digital balance (Model: XL-7100, Denver Instrument Company, Man., USA). The sap was poured into a separate holding container. The graduated cylinder was rinsed with distilled water and dried for subsequent use. Sixteen repeated experiments were conducted. The average bulk density was calculated using Eq. (1):

$$
\rho_{\mathrm{a}}=\left(\frac{\mathrm{m}_{\mathrm{a}}}{\mathrm{V}_{\mathrm{a}}}\right)
$$

Where $\rho_{\mathrm{a}}=$ density of $A$. secundiflora sap $\left(\mathrm{g} / \mathrm{cm}^{3}\right) ; \mathrm{m}_{\mathrm{a}}=$ mass of A. secundiflora sap ( $\mathrm{g}) ; \mathrm{V}_{\mathrm{a}}=$ volume of A. secundiflora $\operatorname{sap}\left(\mathrm{cm}^{3}\right)$.

Water content was determined using freeze-drying methods $[23,24,26]$ in a programmed Freeze Drier (Labconco, FreeZone $^{\circledR}$ Stoppering Tray Drier, Freeze Dry System: Model 79480, Labconco Corporation, USA). Six replicate samples of the sap, each weighing $2.9 \mathrm{~g}$, were placed in the freeze drier and lyophilized for 6 days at a cooling temperature of $-34{ }^{\circ} \mathrm{C}$ a drying temperature of $-5{ }^{\circ} \mathrm{C}$ and vacuum pressure of $133 \times 10^{-3}$ mbar. When the last three readings recorded remained constant, the drying process was stopped. The final masses of the dried sap powder were recorded and percent water loss calculated using Eq. (2):

$$
\mu_{a}=\left(\frac{m_{a}-m_{a d}}{m_{a}}\right) \times 100 \%
$$

Where $\mu_{\mathrm{a}}=$ gravimetric water content of A. secundiflora sap (\%); $m_{a d}=$ mass of dried A. secundiflora $(\mathrm{g})$. The specific heat capacity of A. secundiflora sap was determined using modified calorimetric methods. One-litre of water and one-litre of A. secundiflora sap were heated for 15 minutes using a $1200 \mathrm{~W}$ electric hot plate (ETA 0108, ETA). The temperature change was measured using a mercury thermometer at intervals of 5 minutes. Sensible heat was calculated using Eq. (3). Considering energy balance for water and $A$. secundiflora sap and substituting accordingly, the specific heat capacity of the sap was calculated using Eq. (4).

$$
Q=m \cdot c_{p} . \Delta T
$$

$c_{p a}=\left(\frac{Q_{w}}{m_{a} \Delta T}\right)$

Where $Q=$ heat gain $(\mathrm{J}) ; m=$ mass of substance $(\mathrm{g}) ; c_{p}=$ specific heat capacity at constant pressure $\left(\mathrm{J} / \mathrm{g}^{\circ} \mathrm{C}\right) ; \Delta \mathrm{T}=$ change in temperature $\left({ }^{\circ} \mathrm{C}\right) ; c_{p a}=$ specific heat capacity of A. secundiflora sap at constant pressure $\left(\mathrm{J} / \mathrm{g}{ }^{\circ} \mathrm{C}\right) ; Q_{w}=$ heat gain of water $(\mathrm{J}) ; m_{a}=$ mass of A. secundiflora sap (g).

\subsection{Processing A. Secundiflora Sap Into Paste}

\subsubsection{Assessment of Traditional Processing Methods Using Fuelwood Energy}

A field survey was conducted to collect both quantitative and qualitative data on traditional methods used to process $A$. secundiflora leaf sap into paste in Kinango location, Kinango District, Coast Province of Kenya. A semi-structured questionnaire having both closed and open-ended questions was designed and used to collect the data. Observations and interviews were conducted during traditional processing sessions of A secundiflora paste by 20 of local community dealers who undertook the processing on a regular basis. The data collected and analyzed included mass of sap processed and the paste that was produced per week, the time taken to process the paste, the quantity and source of fuelwood used. A sample of A. secundiflora paste produced traditionally was purchased from a local dealer and transported to Nairobi under cool conditions for comparative analysis.

\subsubsection{Heating Tests Using an Electric Hot Plate}

Laboratory-scale heating tests were conducted to establish thermal characteristics of processing Aloe secundiflora sap into paste. The tests were undertaken in a fume hood using a $1200 \mathrm{~W}$ electric hot plate (ETA 0108, ETA). An aluminium cooking vessel (Table 1), used in the subsequent parabolic solar cooking experiment, was used during the tests. One-litre of sap was poured into a graduated cylinder and weighed to the nearest $0.1 \mathrm{~g}$ using a digital balance (Model: XL-7100, Denver Instrument Company, Man., USA). The sap was transferred into the open aluminium cooking vessel, placed onto the electric hot plate and heated. During processing, the sap was continuously stirred to avoid caking of the material onto the cooking vessel. A calibrated mercury thermometer $\left(-10\right.$ to $\left.250^{\circ} \mathrm{C}\right)$ was used to measure pot content temperature of the sap by positioning it at the centre of the cooking vessel, approximately $1 \mathrm{~cm}$ above the base of the vessel. The temperature was measured and recorded manually. The ambient temperature and relative humidity were continuously measured and stored using 3 data loggers $\left(\mathrm{HOBO}^{\mathrm{TM}}\right.$ Temp/RH Data Logger, Model No. U12011, Onset Computer Corporation, Bourne, MA 02532, USA). The data loggers were mounted at three points in the hood enclosure, $100 \mathrm{~cm}$ from the base of the worktable under the hood. Atmospheric pressure was assumed to be constant. All the parameters were measured at 5 minutes intervals and averaged over 15 minutes during the processing. The test was replicated three times and terminated when the paste formed. The mass of the paste formed was recorded at the end of every test. 


\subsubsection{Thermal Performance Tests Using a Domestic Para-} bolic Solar Cooker

\subsubsection{Domestic Parabolic Solar Cooker}

A conventional SK-14 domestic parabolic solar cooker (EC-Solar eV, Altötting, Germany) was used for testing the thermal performance of processing A. secundiflora sap into paste using solar energy. The parabolic solar cooker reflectors were mounted on a structural steel frame and held tightly using plastic twist ties. The cooker body was held on a steel frame through an opening that made it flexible for manual adjustment. The solar heat was concentrated at a focal point of the detachable pot ring frame containing an aluminium cooking vessel that was supplied with the cooker. Table 1 shows the main specifications of the domestic parabolic solar cooker and the cooking vessel used. No modifications, including heat insulation, were made to the cooker during the testing.

Table 1. Main Specifications of the Parabolic Solar Cooker and Cooking Vessel

\begin{tabular}{|c|c|}
\hline Description & Specification \\
\hline \multicolumn{2}{|c|}{ Parabolic Solar Cooker } \\
\hline Aperture Diameter, $A_{d}(\mathrm{~cm})$ & 140 \\
\hline Aperture area, $A_{p}\left(m^{2}\right)$ & 1.54 \\
\hline Reflector material & Aluminium film (anodized) \\
\hline Focal length $(\mathrm{cm})$ & 30 \\
\hline Receiver diameter $(\mathrm{cm})$ & 21.93 \\
\hline Receiver area $\left(\mathrm{cm}^{2}\right)$ & 378 \\
\hline Optical concentration ratio & 40.74 \\
\hline Capacity (Watts) & 600 \\
\hline \multicolumn{2}{|c|}{ Cooking Vessel } \\
\hline Material & Aluminium (darkened surface) \\
\hline Shape & Cylindrical \\
\hline Capacity (Litres) & 4.6 \\
\hline Inner diameter $(\mathrm{cm})$ & 23.7 \\
\hline Outer diameter $(\mathrm{cm})$ & 23.9 \\
\hline Thickness (cm) & 0.1 \\
\hline Depth $(\mathrm{cm})$ & 10.5 \\
\hline Mass (g) & 200 \\
\hline Length of holding flange $(\mathrm{cm})$ & 2 \\
\hline
\end{tabular}

\subsubsection{Experimental Set-Up and Data Collection}

A semi-field scale experiment for testing the parabolic solar cooker was set-up at Appropriate Technology Centre of Kenyatta University in Nairobi, Kenya located at Latitude $01^{\circ} 10.486 \mathrm{~S}$, Longitude $036^{\circ} 55.995 \mathrm{E}$, Elevation $1550 \mathrm{~m}$ and local boiling temperature of $95^{\circ} \mathrm{C}$. The solar cooker was used outdoors without a heat storage system. The test protocol was based on the ASAE S580 JAN03 Standard method for testing and reporting solar cooker performance [27]. The thermal performance tests were conducted between 10.00am and $4.00 \mathrm{pm}$ under clear sky conditions on July $8^{\text {th }}$ and $9^{\text {th }}$; October $31^{\text {st }}$; and November $17^{\text {th }}$ and $26^{\text {th }}$, 2008. Heating experiments were conducted between $10.00 \mathrm{am}$ and $4.00 \mathrm{pm}$ under clear sky conditions.

Three thermocouples were taped at approximately $120^{\circ}$ onto the empty cooking vessel to measure absorber temperatures. A $2.5 \mathrm{~cm}$ flat steel frame was mounted across the cooker at $175 \mathrm{~cm}$ above the ground and used to support the thermocouples above the cooker. One-litre of homogenous A. secundiflora sap, approximately $8 \mathrm{~kg}$ of the sap per $\mathrm{m}^{2}$ of intercept area of absorber surface (cooking vessel), was loaded into the cooking vessel and placed onto the pot holder. A copper-constantin thermocouple was immersed at the centre of the A. secundiflora sap, $1 \mathrm{~cm}$ above the base of the cooking vessel, to measure the pot content temperature. The cooker was manually adjusted to direct the solar radiation concentrating to the focal point before the heating started and was continuously tracked at 15 to 25 minutes interval from mid-morning to afternoon hours. The cooking vessel was not covered during processing. During heating, the sap was continuously stirred to avoid formation of paste crusts on the cooking vessel. The experiment was terminated when the paste formed. The time taken to heat the sap into paste and final mass of the paste formed was recorded.

Data output readings for temperatures and solar radiation were continuously measured and recorded via a programmed data logger (Model: FLUKE 2286A-Data Logging System, Fluke Corporation, USA) at 10 minutes interval and stored in a floppy disk. Calibrated chromel-alumel thermocouples (0$\left.100^{\circ} \mathrm{C}\right)$ and copper-constantin thermocouple $\left(0-350^{\circ} \mathrm{C}\right)$ with average sensitivity of $42 \mu \mathrm{V} /{ }^{\circ} \mathrm{C}$ were used to measure ambient (AMB T1), absorber (ABS T2) and pot content (POTC T3) temperatures in ${ }^{\circ} \mathrm{C}$. The thermocouples were terminated to the data logger. Solar radiation was measured in millivolts $(\mathrm{mV})$ using a pyranometer (Model: CN77-277, Middleton Instruments, Australia) with short-wave sensitivity of $9.8 \mathrm{mV} / \mathrm{kWm}^{-2}$. The interval solar radiation in $\mathrm{W} / \mathrm{m}^{2}$ was determined by multiplying the $\mathrm{mV}$ readings by a correlation factor of 91.68 [28]. The pyranometer was mounted on the rooftop of the building at approximately $1000 \mathrm{~cm}$ above the ground level and terminated to the data logger via a thermocouple. Wind velocity and cloud cover data were observed at intervals of 10 minutes and recorded manually. The wind velocity was measured in $\mathrm{m} / \mathrm{s}$ using a hand-held digital anemometer (VELOCALC ${ }^{\circledR}$ TSI $_{\circledast}$, Model 7357, TSI Inc. St. Paul, MN, USA), which was mounted on a steel frame $100 \mathrm{~cm}$ away from the cooker with the probe at $180 \mathrm{~cm}$ above the ground. Cloud cover was observed using a digital thermo hygrometer incorporating a digital clock (Maxipine ${ }^{\circledR} \mathrm{Ce}$ fepime, Clip Sonic Technology, PR.C. Design). Fig. (3) and (4) show the schematic diagram and picture of the experimental set-up respectively.

\subsection{Chromatographic Analysis of A. Secundiflora Leaf Sap and Paste}

Aloin content in A. secundiflora sap and paste was analyzed using High Pressure Liquid Chromatography (HPLC) methods described by Waihenya [10]. The HPLC was performed using a HP 1090 Series II system equipped with an auto-sampler, two P4000 gradient pumps and a UV 6000 photodiode array detector (200-500nm range; $5 \mathrm{~nm}$ band- 


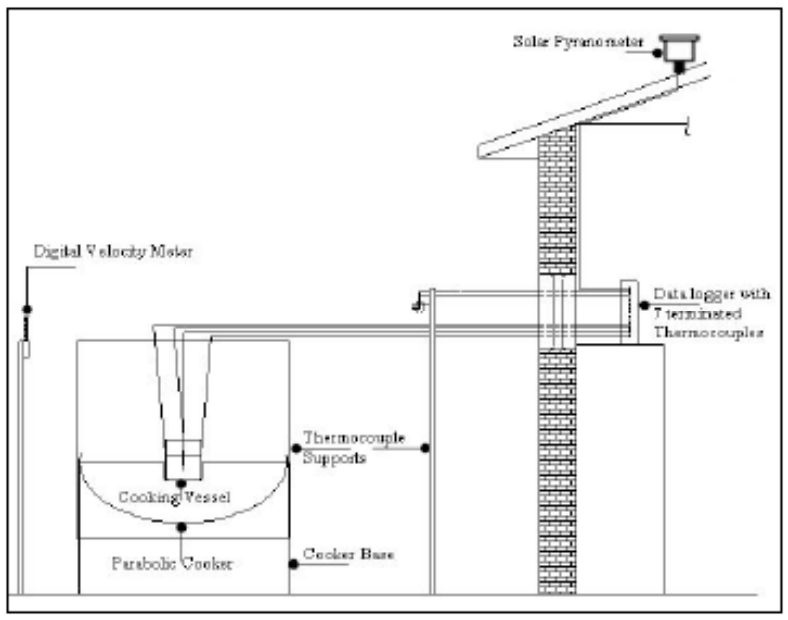

Fig. (3). Schematic diagram of the experimental set-up: Not to scale.

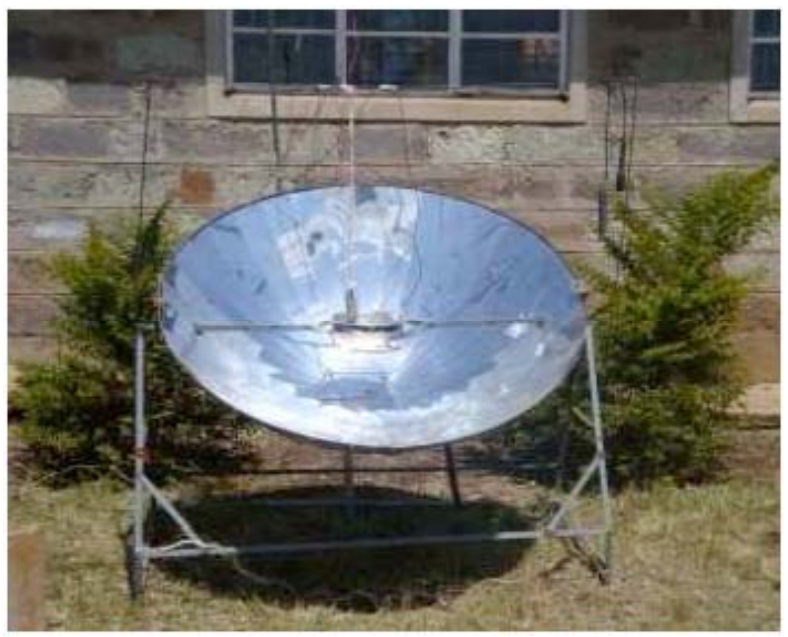

Fig. (4). Processing A. secundiflora sap using a domestic parabolic solar cooker.

width) controlled by ChromQuest ${ }^{\mathrm{TM}}$ software (Thermo Fisher Scientific Inc., USA). Analyses were performed using a C18 column $(150 \mathrm{~mm} \times 4.6 \mathrm{~mm}$ i.d.; $5 \mu \mathrm{m})$. The mobile phase comprised of acetonitrile (solvent A) and water (solvent B) with both solvents containing $0.01 \%$ trifluoroacetic acid. The gradient programme commenced at 95:5 (v/v) of A: B followed by a linear gradient for $50 \mathrm{~min}$ to $78: 22$ (A: B) and for $25 \mathrm{~min}$ to $60: 40$ (A: B). The total running time was $75 \mathrm{~min}$ with a flow rate of $1 \mathrm{~mL} / \mathrm{min}$. All chemicals that were used in the analyses were of analytical grade: solvents were of HPLC grade and purchased from Merck (Darmstadt, Germany). Ultrapure distilled water was employed in all experiments. Reference samples of Aloin A (Barbaloin) standard compound were purchased from Roth (Karlsruhe, Germany). Samples of the sap and paste were prepared separately by diluting $1 \mathrm{mg}$ of sap and $1 \mathrm{mg}$ of paste in $3 \mathrm{~mL}$ of $30 \%(\mathrm{v} / \mathrm{v})$ aqueous methanol and centrifuging at $13000 \mathrm{rpm}$ for $5 \mathrm{~min} .200 \mu \mathrm{L}$ of supernatant was withdrawn from each sample prepared and placed into an insert for HPLC analysis where $5 \mu \mathrm{L}$ of the barbaloin standard was added. The sample volume for the sap and paste samples analyzed separately was $20 \mu \mathrm{L}$. Quantification was performed by calculating the area of each peak detected at $290 \mathrm{~nm}$ as a percentage of the total area of the peaks observed in three measurements. With a $100 \%$ resolution assumption of the injected standard solution, identification of aloin compound was done using methods described by Zonta [29, 30].

\subsection{Statistical Analysis}

Data was analyzed using GenStat and Microsoft Excel. The analysis included ANOVA General Treatment Structure (No blocking), negative binomial and polynomial regressions.

2.6. Construction of a Community-Based Facility for Pilot-Scale Processing A. Secundiflora Sap Into Paste Using an Elliptical Parabolic Solar Concentrator

Following the successful demonstration of the potential of solar energy for processing A. secundiflora sap into paste under semi-field conditions, a community-based facility for pilot-scale processing of $A$. secundiflora sap into paste was constructed at Kinango in Kinango District in the Coast Province of Kenya. An elliptical parabolic solar concentrator [Wolfgang Scheffler Design, Solare Brucke, Aislingenre, Germany] was installed at the facility located at Latitude $04^{\circ} 9.130 \mathrm{~S}$, Longitude $39^{\circ} 19.300 \mathrm{E}$ and Elevation $178 \mathrm{~m}$. Fig. (5), (6) and (7) show the schematic diagram and photograph

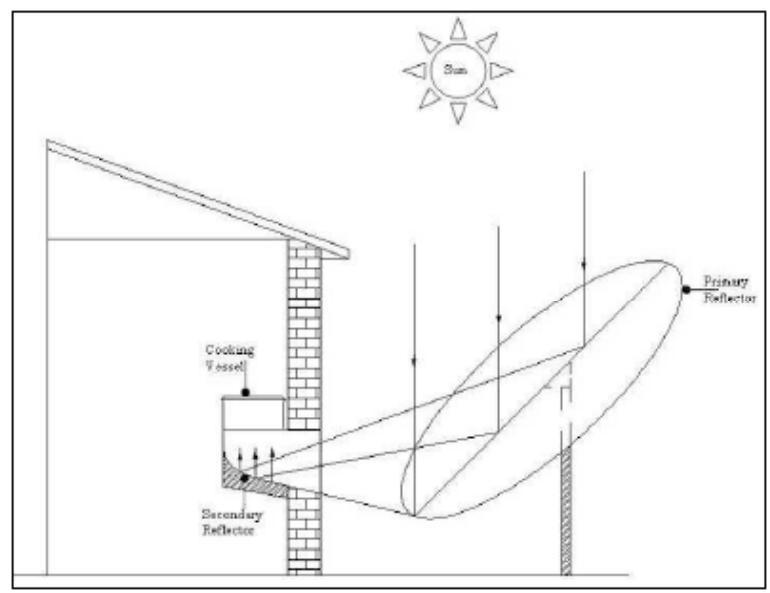

Fig. (5). Schematic diagram of the field-scale solar concentrator: Not to scale solar cooker.

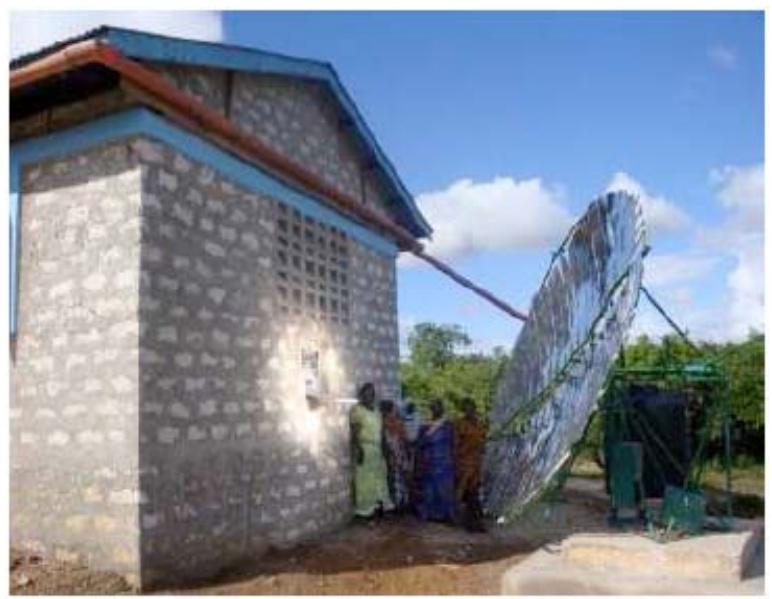

Fig. (6). Field-scale solar concentrator installed at Kinango, Kinango District, Kenya. 


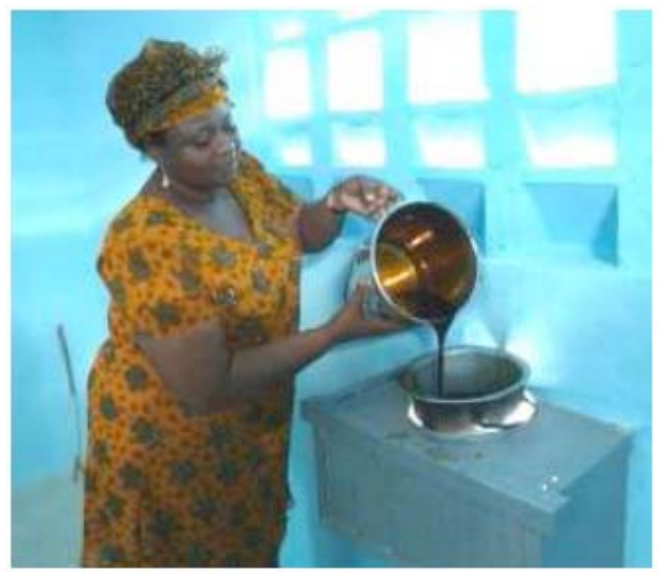

Fig. (7). A community member processing A. secundiflora sap using the field-scale solar concentrator at Kinango.

of the solar concentrator installed at the processing facility, and photograph of a community member processing $A$. secundiflora sap within the facility.

\subsubsection{The Elliptical Parabolic Solar Concentrator System}

The elliptical parabolic solar concentrator system comprised of an elliptical parabolic dish as the primary reflector, mounted on a rotating support arm; a support frame for the rotating arm; a mechanical tracking system comprising of a clock, drive chain and a $50 \mathrm{~kg}$ torque weight; a pot holder fitted with a fixed focus secondary reflector mounted inside the processing room and a cooking vessel. Table 2 shows the main specifications of the solar concentrator. The concentrator was supplied with a 20-litres mild steel cooking vessel, having selective SOLKOTE surface paint.

Table 2. Main Specifications of the parabolic solar concentrator

\begin{tabular}{|c|c|}
\hline Description & Specification \\
\hline \multicolumn{2}{|c|}{ Parabolic Solar Concentrator } \\
\hline Aperture Length, $A_{L}(\mathrm{~cm})$ & 387.6 \\
\hline Aperture Width, $\mathrm{A}_{\mathrm{w}}(\mathrm{cm})$ & 274 \\
\hline Primary Reflector Area, $\mathrm{A}_{\mathrm{rp}}\left(\mathrm{m}^{2}\right)$ & 8 \\
\hline Aperture area, $A_{p}\left(m^{2}\right)$ & 5.66 \\
\hline Secondary Reflector Area, $\mathrm{A}_{\mathrm{rs}}\left(\mathrm{m}^{2}\right)$ & 0.2 \\
\hline Primary Reflector material & Alcan specialty solar sheet \\
\hline Secondary Reflector material & Aluminium film anodized \\
\hline Focal length of Primary Reflector (cm) & 287 \\
\hline Optical concentration ratio & 30 \\
\hline Average Cooking power (W) & 2200 \\
\hline
\end{tabular}

The parabolic dish was mounted in a North-South orientation, with the axis of rotation aligned parallel to the earth surface and at the centre of both reflectors. The concentrating dish operates by converging sunlight beams onto a fixed focus secondary reflector and reflects the rays onto the cooking vessel. The mechanical clock mechanism rotates the primary reflector along its axis of rotation and maintains the
Table 3. Yield of A. Secundiflora Leaf Sap from 3 Sites in Kinango District

\begin{tabular}{|c|c|}
\hline Site & Average A.secundflora sap yield (mL) \\
\hline \hline 1 & $3.60 \pm 1.30$ \\
\hline 2 & $5.00 \pm 0.45$ \\
\hline 3 & $4.10 \pm 0.86$ \\
\hline Overall average yield & $4.20 \pm 0.40$ \\
\hline
\end{tabular}

Table 4. The Average Gravimetric Water Content, Bulk Density and Specific Heat of the A. Secundiflora Sap

\begin{tabular}{|c|c|}
\hline Parameter & Average value \\
\hline \hline Bulk density at $21^{\circ} \mathrm{C}\left(\mathrm{g} \mathrm{cm}^{-3}\right)$ & $1113.70 \pm 2.60$ \\
\hline The gravimetric water content $(\%)$ & $81.30 \pm 0.10$ \\
\hline Specific heat capacity $(\mathrm{J} / \mathrm{g} \mathrm{K})$ & $3.40 \pm 0.12$ \\
\hline
\end{tabular}

reflected beams aligned to this axis as the sun moves. To counter seasonal variations during the year, the parabolic dish was tilted vertically or horizontally once a week using two built-in leavers in the support frame. Tilting maintained the focal point of the reflected beam.

\subsubsection{Operation of the Elliptical Parabolic Solar Concen- trator System}

In the morning, the parabolic dish was rotated manually to the starting position where the secondary reflector illuminated. The solar dish was designed to track the movement of the sun by the gravity driven mechanical devise fitted with a clutch. The clock was started by pressing the clutch arm slowly. The focus of the sunlight beam was maintained at the secondary reflector position throughout the day. The angle between the axis of rotation and the primary reflector was continuously adjusted to maintain a fixed focus at the secondary reflector. The secondary reflector was inclined to reflect the focused beams sideways around the cooking vessel.

\section{RESULTS AND DISCUSSION}

\subsection{A. Secundiflora Sap}

The average yield of $A$. secundiflora leaf sap harvested from 3 sites in Kinango, Kinango District in the Coast Province of Kenya is given in Table 3. The overall average yield per leaf was $4.2 \pm 0.4 \mathrm{~mL}$. The A. secundiflora sap was dark brown in colour. When stored at $4^{\circ} \mathrm{C}$, the sap maintained a non-solidified uniformity for the first week and separated into three layers by the second week. It was therefore necessary to stir the sap to homogeneity before commencement of the experiments. Table 4 shows the average values of water content, bulk density and specific heat capacity of the $A$. secundiflora sap.

\subsection{Traditional Processing of A. Secundiflora Sap Into Paste}

Results from the field survey on traditional processing of A. secundiflora sap into paste using fuelwood energy in $\mathrm{Ki}$ nango District of Kenya are presented in Table 5. It was established that on a weekly basis, 20 of the commercial pro- 
Table 5. Summarized Field Survey Results on Traditional Processing of A. secundiflora SAP into Paste Using Fuelwood

\begin{tabular}{|c|c|}
\hline Parameter & Average Value \\
\hline \hline Mass of sap $(\mathrm{g})$ & 445480 \\
\hline Mass of paste $(\mathrm{g})$ & 228530 \\
\hline Heating time per process $(\mathrm{min})$ & 270 \\
\hline Quantity of fuelwood used $(\mathrm{g})$ & 941180 \\
\hline
\end{tabular}

Table 6. Summary Results During Processing of A. Secundiflora Sap into Paste Using an Electric Hot Plate

\begin{tabular}{|c|c|}
\hline Parameter & Average Value \\
\hline \hline Mass of sap $(\mathrm{g})$ & $1113.70 \pm 0.00$ \\
\hline Mass of paste $(\mathrm{g})$ & $418.50 \pm 8.00$ \\
\hline Heating time $(\mathrm{min})$ & $75.00 \pm 0.00$ \\
\hline Water loss $(\%)$ & $62.40 \pm 0.70$ \\
\hline Ambient temperature $\left({ }^{\circ} \mathrm{C}\right)$ & $26.30 \pm 0.10$ \\
\hline Pot content Temperature $\left({ }^{\circ} \mathrm{C}\right)$ & $76.40 \pm 7.40$ \\
\hline
\end{tabular}

ducers processed $445480 \mathrm{~g}$ of the sap to produce $228530 \mathrm{~g}$ of the paste. The results showed that approximately $1000 \mathrm{~g}$ of the sap produced $513 \mathrm{~g}$ of paste while approximately $4119 \mathrm{~g}$ of fuelwood was required to produce $1000 \mathrm{~g}$ of the paste. About $10 \%$ of the fuelwood was purchased, $76 \%$ harvested from trees and $14 \%$ collected from shrubs and twigs. The fuelwood preferably used was mainly wet or semi-dry, and thus heavy.

\subsection{Thermal Performance Tests of Processing $A$. Secundiflora Sap Using the ELECTRIC Hot Plate}

Table 6 shows a summary of results of the thermal performance tests of $A$. secundiflora sap using an electric hot plate. The time taken to process A. secundiflora sap into paste was constant at 75 minutes irrespective of the initial temperature of the sap before heating commenced. The pot content temperature rose up to a mean maximum of $94^{\circ} \mathrm{C}$ and then dropped to $93^{\circ} \mathrm{C}$ when the paste began to form. After the paste had formed, the pot content temperature dropped to an average of $90.30^{\circ} \mathrm{C}$. Fig. (8) shows the temperature profile generated for processing A. secundiflora sap into paste. Results revealed that temperatures in the range of $90-100^{\circ} \mathrm{C}$ were sufficient for processing A. secundiflora sap into paste.

\subsection{Thermal Performance of Processing A. Secundiflora Sap Using the Parabolic Solar Cooker}

Table 7 gives a summary of the thermal performance of the domestic parabolic solar cooker in processing A. secundiflora sap into paste. The performance of the solar cooker depended on solar radiation and ambient and pot content temperatures, which determined the heating time required to convert the leaf sap into paste. Variations in solar radiation and wind velocity were observed. The shortest heating time
Table 7. Summarized Results Showing Thermal Performance of the Domestic Parabolic Solar Cooker in Processing A. Secundiflora Sap Into Paste

\begin{tabular}{|c|c|}
\hline Parameter & Average Value \\
\hline \hline Yield of paste $(\mathrm{g})$ & $247.60 \pm 16.50$ \\
\hline Heating Time (Minutes) & $206.00 \pm 35.90$ \\
\hline Water Loss $(\%)$ & $77.77 \pm 1.50$ \\
\hline Cooker Efficiency $(\%)$ & $31.00 \pm 2.90$ \\
\hline Ambient Temperature $\left({ }^{\circ} \mathrm{C}\right)$ & $28.00 \pm 0.20$ \\
\hline Absorber Temperature $\left({ }^{\circ} \mathrm{C}\right)$ & $80.10 \pm 2.80$ \\
\hline Pot Content Temperature $\left({ }^{\circ} \mathrm{C}\right)$ & $62.50 \pm 1.80$ \\
\hline Solar Radiation $\left(\mathrm{W} / \mathrm{m}^{2}\right)$ & $769.00 \pm 14.00$ \\
\hline Wind Velocity $(\mathrm{m} / \mathrm{s})$ & $1.10 \pm 0.10$ \\
\hline
\end{tabular}

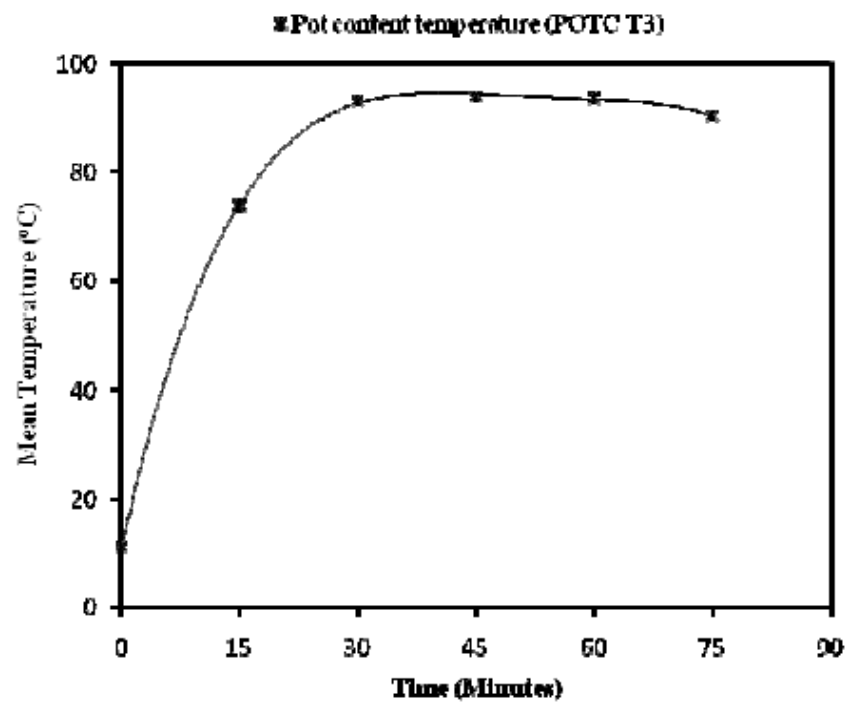

Fig. (8). Temperature profile during processing of A. secundiflora sap into paste using the electric hot plate.

was recorded on day 2 while the longest occurred on day 4 . This could be attributed to the high and constant solar radiation on day 2 , and the highly variable solar radiation on day 4. In addition, there was a lower average wind velocity on day 2 compared to day 4 . On day 4 , the minimum solar radiation was below the recommended value of $450 \mathrm{~W} / \mathrm{m}^{2}$ while the wind velocity was above the recommended value of $2.5 \mathrm{~m} / \mathrm{s}$. The variations in solar radiation and ambient, absorber and pot content temperatures for day 1 and 4 presented in Fig. (9) and Fig. (10) illustrate the effect of solar radiation on the performance of the solar cooker. Results showed that wind velocity had no significant effect on the heating time. Absorber temperatures continuously fluctuated even at high solar radiation. This could be attributed to a shift in the focus of the sun's beam that was reflected onto the cooking vessel during tracking of the parabolic solar cooker, which in turn affected the pot content temperature of the A. secundiflora sap. The yield of A. secundiflora paste was lower on day 4 , which could be explained by the longer 


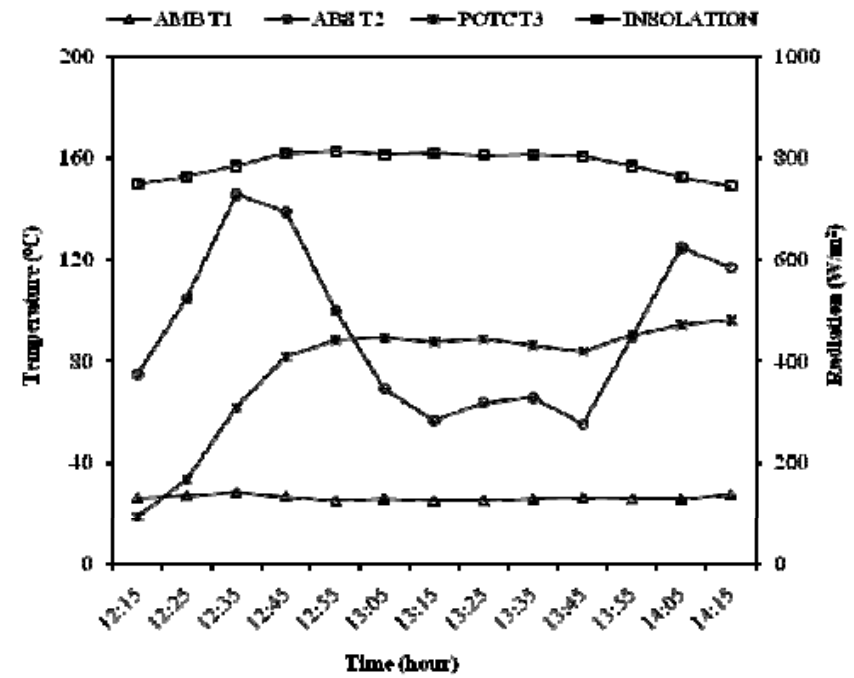

Fig. (9). Solar radiation and temperature profiles during Day 1 of processing using solar parabolic cooker.

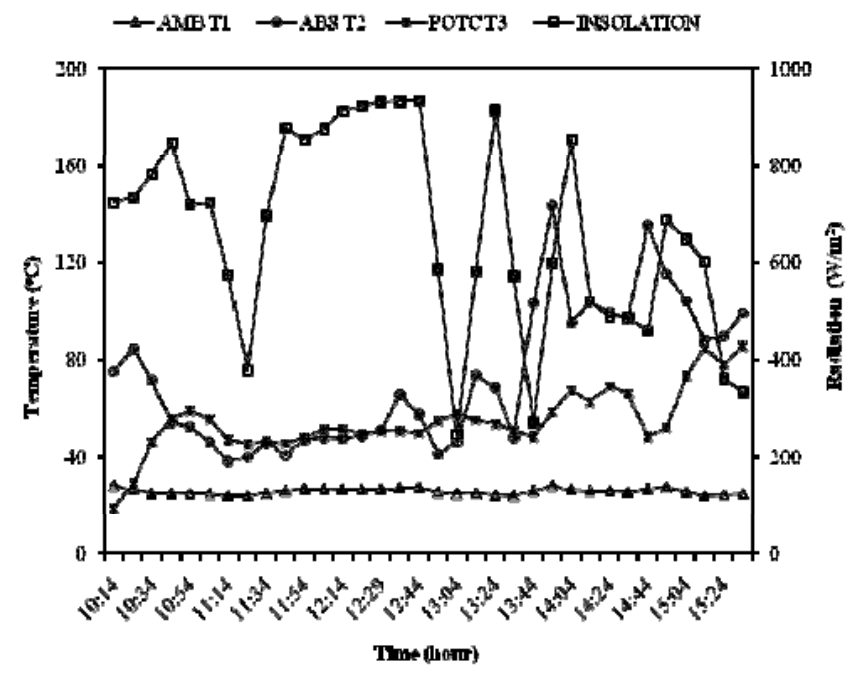

Fig. (10). Solar radiation and temperature profiles during Day 4 of processing using solar parabolic cooker.

heating time that caused higher losses of some of the more volatile constituents in the leaf sap.

\subsection{Quality of Processed A. Secundiflora Paste}

Table 8 shows the results from the high performance liquid chromatography (HPLC) analysis of Aloin A (Barbaloin) content in A. secundiflora leaf sap and A. secundiflora paste processed using fuelwood, electricity and solar energy. The Aloin A content was found to be highest in A. secundiflora sap followed by paste processed using solar, electricity and fuelwood energy respectively.

\subsection{Determination of Energy Requirements for Process- ing A. Secundiflora Paste}

Sensible and latent heat energies of electricity and solar parabolic cookers were determined and their difference from energy input considered as heat loss. Unit conversion of 1 $\mathrm{kWh}=3.6 \times 10^{6} \mathrm{~J}$ was used. For the electric hot plate, power input was equivalent to the power rating $(1200 \mathrm{~W})$. The en-
Table 8. Percentage content of Aloin in processed and unprocessed $A$. secundiflora

\begin{tabular}{|c|c|}
\hline Source & Aloin A content (\%) \\
\hline \hline Leaf sap & 40.96. \\
\hline Paste processed using fuel wood & 32.00 \\
\hline Paste processed using electricity & 36.30 \\
\hline Paste processed using solar energy & 37.50 \\
\hline
\end{tabular}

ergy input would then be the rating multiplied by the average heating time (75 minutes) taken to process $A$. secundiflora leaf sap into paste.

$$
\begin{aligned}
\text { Energy input } & =\left[1.2 \times(75 / 60) \times 3.6 \times 10^{6}\right] \mathrm{J} \\
& =5.40 \times 10^{6} \mathrm{~J}
\end{aligned}
$$

The temperature profile of $A$. secundiflora leaf sap during the heating process showed a polynomial cubic function. The energy output was calculated as sensible heat required to raise the temperature of $A$. secundiflora leaf sap from 11.20 $94.00{ }^{\circ} \mathrm{C}$ and latent internal heat as the sap changed phase from liquid slurry to paste. To calculate sensible heat, the parameters established for A. secundiflora leaf sap were substituted in Eq. (3),

Sensible heat

$$
\begin{aligned}
& =1113.70 \times 3.4[94.00-11.20] \mathrm{J} \\
& =313.53 \times 10^{3} \mathrm{~J}
\end{aligned}
$$

During paste formation, heat was released and the temperature dropped from $94.00-90.30^{\circ} \mathrm{C}$, thereby creating a positive latent heat flux. During the phase change, water evaporated from the sap and it was assumed that the latent internal heat of vaporization [See: Eq. (5)] [18] was that of the water that evaporated.

$Q_{L}=m_{e v} \cdot L_{h v}$

Where $Q_{L}=$ latent internal heat $(\mathrm{J}) ; \mathrm{m}_{\mathrm{ev}}=$ mass of water that evaporated $(\mathrm{g}) ; \mathrm{L}_{\mathrm{hv}}=$ latent heat of vaporization for water $(\mathrm{J} / \mathrm{g})$. By substitution,

$$
\begin{aligned}
Q_{L} & =[(1113.7-418.5) \times 2260] \mathrm{J} \\
& =1.571 \times 10^{6} \mathrm{~J}
\end{aligned}
$$

The energy required to process $A$. secundiflora sap into paste is Sensible heat + Latent heat

$$
\begin{aligned}
& =\left[(0.31353+1.571) \times 10^{6}\right] \mathrm{J} \\
& =1.884 \times 10^{6} \mathrm{~J} .
\end{aligned}
$$

Therefore, the energy efficiency, $\eta=$ Sensible heat + Latent heat]/[Electric Energy Input]

$$
\begin{aligned}
= & \frac{\left[1.884 \times 10^{6}\right] \times 100 \%}{5.40 \times 10^{6}} \\
= & 34.89 \%
\end{aligned}
$$

For the parabolic solar cooker, the power input was a function of solar radiation and aperture area of the cooker [See: Eq. (6)] [16]. The energy output would then be the power input multiplied by heating time taken to process the sap. With reference to Table $\mathbf{1}$ and using average values, 
Table 9. Summary of Results to Show Temperatures and Solar Cooker Heat Efficiency

\begin{tabular}{|c|c|c|c|}
\hline Parameter & Minimum & Maximum & Average \\
\hline A. secundiflora $\mathrm{POTC} \mathrm{T} 3$ temperature $\left({ }^{\circ} \mathrm{C}\right)$ & 19.00 & 96.30 & 62.50 \\
\hline Interval POTC T3 temperature difference $\left({ }^{\circ} \mathrm{C}\right)$ & 0.10 & 28.35 & 6.49 \\
\hline $\begin{array}{c}\text { Interval temperature difference }\left({ }^{\circ} \mathrm{C}\right) \\
{[\Delta \mathrm{T}=\mathrm{ABS} \mathrm{T} 2-\mathrm{AMB} \mathrm{T} 1]}\end{array}$ & -3.20 & 68.6 & 36.6 \\
\hline Energy output $\left(\mathrm{J} .10^{3}\right)$ & 0.38 & 107.35 & 25.83 \\
\hline Power output (W) & 0.63 & 178.92 & 43.05 \\
\hline Sensible heating efficiency (\%) & 0.04 & 16.01 & 3.73 \\
\hline
\end{tabular}

$$
P=I \cdot A_{p}
$$

Where $I=$ solar radiation $\left(\mathrm{W} / \mathrm{m}^{2}\right) . A_{p}=$ aperture area $\left(\mathrm{m}^{2}\right)$.

$$
\begin{aligned}
= & (769 \times 1.54) \mathrm{W} \\
= & 1.18 \mathrm{~kW} \\
= & {[1.18 \times(206 / 60) \times} \\
& \left.3.6 \times 10^{6}\right] \mathrm{J} \\
= & 14.64 \times 10^{6} \mathrm{~J}
\end{aligned}
$$

Average Energy input

Table 9 gives a summary of results for temperature and energy efficiency of the solar parabolic cooker system. Constant mass of A. secundiflora sap was used in the calculation of sensible heat output for each 10 minutes interval during processing. Sensible heat efficiency of the parabolic solar cooker was calculated using Eq. (7) [16]. The efficiency of the domestic parabolic solar cooker varied from 0.04 $16.01 \%$, with an average of $3.73 \%$. This efficiency variation could be attributed to solar insolation and ambient temperature, and the absence of insulation which could have resulted in heat losses.

$\eta=\frac{\left(\frac{\mathrm{m}_{\mathrm{a}} \cdot \mathrm{c}_{\mathrm{pa}} \cdot \Delta \mathrm{T}}{\Delta \mathrm{t}}\right)}{\mathrm{I}_{\mathrm{A}} \mathrm{A}_{\mathrm{p}}} \times 100 \%$

Eq. (6) was used to calculate the latent internal heat that evaporated $866.10 \mathrm{~g}$ of water [See: Table 7], which was found to be $1.96 \times 10^{6} \mathrm{~J}$. The latent heat efficiency was found to be $13.37 \%$ using the system average energy input of $14.64 \times 10^{6} \mathrm{~J}$. Using the average values, the overall heat transfer coefficient was calculated using Eq. (8) [31].

$$
U=\frac{\left(1-\eta_{e}\right) A_{p} \dot{I}}{\left(T_{A B S T 2}-T_{A M B T 1}\right)}
$$

Where $U=$ heat transfer coefficient $\left(\mathrm{W} / \mathrm{m}^{2} \mathrm{~K}\right) ; \eta=$ sensible heat efficiency $(\%) ; \eta_{e}=$ overall heat [sensible + latent $]$ efficiency $(\%) ; \Delta \mathrm{t}=$ interval time (10 minutes).

$$
\begin{aligned}
\text { Cooker system efficiency, } \eta_{e}= & (3.73+13.37) \% \\
= & 17.10 \% \\
\text { Overall heat transfer coefficient }= & {[(1-0.171) \times \quad 769] / } \\
& {[36.6] \mathrm{W} / \mathrm{m}^{2} \mathrm{~K} } \\
= & 17.40 \mathrm{~W} / \mathrm{m}^{2} \mathrm{~K}
\end{aligned}
$$

Comparatively and where water has been used to test parabolic solar cookers, energy efficiencies of $2.8-15.7 \%$ [16] and 26.6\% [17] have been attained.

\subsection{Annual Green House Gas Emission Saving when Solar and Electricity Energy was Used}

Fuelwood energy used to process A. secundiflora paste contributes to direct and indirect emission of greenhouse gases including carbon dioxide $\left(\mathrm{CO}_{2}\right)$ and methane $\left(\mathrm{CH}_{4}\right)$. Based on the results presented in Table $\mathbf{5}$ and literature values of carbon (C) in fuelwood [32], some assumptions were made for ease of computing direct and indirect $\mathrm{CO}_{2}$ emissions.

\subsubsection{Direct Carbon Dioxide Emission}

Assumptions: Constant processing of $445480 \mathrm{~g}$ of $A$. secundiflora sap per week for 48 weeks annually by 20 of the local dealers in Kinango District, Kenya covered by the survey.

Constant yield of $228530 \mathrm{~g}$ A. secundiflora paste per week for 48 weeks annually processed by the 20 dealers.

Approximately 10.97 tonnes of A. secundiflora paste produced per year by the 20 dealers.

$35 \%$ Carbon is found in fuelwood [32]

Carbon $(\mathrm{C})+$ Oxygen $\left(\mathrm{O}_{2}\right)=$ Carbon dioxide $\left(\mathrm{CO}_{2}\right)$

To produce 10.97 tonnes of paste annually, 45.20 tonnes of fuelwood are used. The $35 \%$ Carbon found in the 45.20 tonnes of fuelwood is $=(0.35 \times 45.2)$ tonnes $=15.82$ tonnes of carbon

Hence, $\mathrm{CO}_{2}$ saving per year $=15.82 \times(44 / 12)$ tonnes $\approx 58.01$ tonnes

\subsubsection{Indirect Carbon Dioxide Emission}

Uncut trees sequester $\mathrm{CO}_{2}$, which is indirectly emitted when trees are cut for fuelwood energy use. Assumptions used were [32]:

1 tree

1 hectare (ha)

$\mathrm{CO}_{2}$ absorbed/ha
$=0.3$ tonnes of fuelwood

$=100$ trees

$=30$ tonnes 
For 45.20 tonnes of fuelwood used annually, the equivalent number of trees cut

$\begin{aligned} & =45.20 \div 0.30 \text { trees } \\ & \approx 151 \text { trees } \\ \text { Therefore the size of land } & =(151 \div 100) \text { ha } \\ \text { Total } \mathrm{CO}_{2} \text { absorbed annually } & =(1.50 \times 30) \text { tonnes } \\ & =45.30 \text { tonnes. }\end{aligned}$

Therefore, when solar or electricity energy is used as substitute for fuelwood energy to process 10.97 tonnes of $A$. secundiflora paste, the $\mathrm{CO}_{2}$ green house gas emission saved would be $(58.01+45.30)=103.31$ tonnes.

\section{CONCLUSION AND RECOMMENDATIONS}

In this study A. secundiflora leaf sap was found to constitute very high percentage $(81.30 \%)$ of water. This is a property that necessitates heat treatment of A. secundiflora leaf sap to remove excess water to form a stable paste product. If not removed, the high water content normally leads to deterioration of the Aloe leaf sap due to microbial attack and breakdown [23, 24]. The traditional methods of processing A. secundiflora leaf sap into paste utilize approximately 4 $119 \mathrm{~g}$ of fuelwood that is purchased or sourced directly from trees and shrubs in the surrounding semi-arid areas to process 1 tonne of the paste.

In the case study involving 20 commercial dealers in Kinango District, an estimated 10.97 tonnes of A. secundiflora paste is produced annually using an estimated 45.20 tonnes of fuelwood. This would translate to annual clearing of approximately 151 trees covering an estimated 1.51 ha of forest land to obtain the required fuelwood. Taking into account the fact that the case study was a small sample of the population in Arid and semi-arid parts of Africa that is involved in the trade, the large quantities of fuelwood used not only contribute to deforestation and loss of biodiversity but also to carbon dioxide green house gas emissions, whose long term effects include environmental and land degradation and climate change respectively. Hence, the use of solar or electricity energy types would reduce the negative effects of using fuelwood energy.

Based on the results of this study, solar concentration technology is an attractive alternative to using fuelwood to process A. secundiflora leaf sap into paste. The temperature range of $90-100^{\circ} \mathrm{C}$ that was required to process $A$. secundiflora sap into paste could be easily attained by solar cookers. Solar energy is free and abundant especially in the semi-arid and arid areas of Africa where A. secundiflora grows.

A. secundiflora paste produced using solar energy showed a higher content of Aloin A (37.20\%) compared to electricity $(36.30 \%)$ and fuelwood (32.00\%) energy. Aloin A (or Barbaloin) is an anthraquinone glycoside which is a bitter, yellow-brown colored compound found in the exudates of at least 68 Aloe species [33, 34]. It is used as a stimulantlaxative in treating constipation and as a bittering agent in commercial alcoholic beverages $[1,5,30]$. Aloin content is generally used as a standard measure of the quality of Aloe extracts $[30,35]$. The higher the Aloin content, the higher the value of the Aloe extracts. The variations in Aloin content in A. secundiflora paste produced using solar, electricity and fuelwood energy could be attributed to possible changes in thermo-chemical reactions in the sap with likely overheating when using fuelwood, and gentle heating when using electricity and solar energy.

Solar energy was more efficient in reducing the water content of A. secundiflora leaf sap by $77.77 \%$ compared to electricity $(62.40 \%)$ and fuelwood $(48.70 \%)$ energy, thereby providing a more stable paste. Improvements on the parabolic solar cooker system would include modification and insulation of the potholder to store energy and minimization of heat losses are recommended in further research. It is expected that results from the pilot-scale processing of $A$. secundiflora sap into paste using the elliptical parabolic solar concentrator installed at the community-based facility in Kinango District in Kenya will provide more insight into the feasibility of applying solar concentrating technology in rural processing of A. secundiflora paste.

\section{ACKNOWLEDGEMENT}

The authors would like to thank the Biovision Foundation, Critical Ecosystem Partnership Fund-Conservation International [CEPF-CI] and Ford Foundation for providing financial support for carrying out this study. The authors also acknowledge the Appropriate Technology Centre at Kenyatta University for hosting the research study, Dr. Ian Gordon for encouragement, guidance support and Dumbule Women Group, a self-help community-based group that owns and manage the processing facility in Kinango where the field trials are being conducted.

\section{CONFLICT OF INTEREST}

None Declared.

\section{NOMENCLATURE}

\begin{tabular}{|c|c|c|}
\hline$\%$ & $=$ & Percent \\
\hline o & $=$ & Degree \\
\hline$\mu 1$ & $=$ & Microlitre \\
\hline$\mu \mathrm{m}$ & $=$ & Micrometre \\
\hline$\mu \mathrm{V} /{ }^{\circ} \mathrm{C}$ & $=$ & Microvolt per degree centigrade \\
\hline${ }^{\circ} \mathrm{C}$ & $=$ & Degrees centigrade \\
\hline ABS T2 & $=$ & Absorber temperature (T2) \\
\hline AMB T1 & $=$ & Ambient temperature (T1) \\
\hline $\mathrm{cm}$ & $=$ & Centimetre \\
\hline g & $=$ & gram \\
\hline HPLC & $=$ & High Pressure Liquid Chromatography \\
\hline ha & $=$ & Hectares \\
\hline i.d & $=$ & internal diameter \\
\hline $\mathrm{J}$ & $=$ & Joules \\
\hline $\mathrm{J} / \mathrm{g}$ & $=$ & Joules per gram \\
\hline $\mathrm{J} / \mathrm{g}^{\mathrm{o}} \mathrm{C}$ & $=$ & Joules per gram per degree centigrade \\
\hline $\mathrm{kg}$ & $=$ & Kilogram \\
\hline $\mathrm{kg} / \mathrm{m}^{3}$ & $=$ & Kilogram per cubic metre \\
\hline $\mathrm{m} / \mathrm{s}$ & $=$ & Metres per second \\
\hline
\end{tabular}




\begin{tabular}{|c|c|c|}
\hline mbar & $=$ & Millibar \\
\hline $\mathrm{mg}$ & $=$ & Milligram \\
\hline $\min$ & $=$ & Minute \\
\hline $\mathrm{mL}$ & $=$ & Millilitre \\
\hline $\mathrm{mL} / \mathrm{min}$ & $=$ & Millilitres per minute \\
\hline $\mathrm{mm}$ & $=$ & Millimetre \\
\hline $\mathrm{mV} / \mathrm{kW} \mathrm{m} \mathrm{m}^{-2}$ & $=$ & Millivolt per kilowatt per square metre \\
\hline $\mathrm{nm}$ & $=$ & Nanometre \\
\hline РОТС Т3 & $=$ & Pot content temperature (T3) \\
\hline UV & $=$ & Ultra-violet \\
\hline $\mathrm{v} / \mathrm{v}$ & $=$ & volume in volume concentration \\
\hline $\mathrm{W}$ & $=$ & Watt \\
\hline $\mathrm{W} / \mathrm{m}^{2}$ & $=$ & Watt per square metre \\
\hline $\mathrm{W} / \mathrm{m}^{2} \mathrm{~K}$ & $=$ & Watt per square metre per degree Kelvin \\
\hline
\end{tabular}

\section{REFERENCES}

[1] Newton, L. E., Aloe secundiflora Engl. In Medicinal plants/plantes médicinales 1, Schmelzer, G. H. G.-F., A., Ed. Prota 11(1):.[CDRom], PROTA: Wageningen, Netherlands, 2006.

[2] Carter, S., Aloaceae. In Flora of Tropical East Africa, Polhill, R. M., Ed. A.A. Balkema: Rotterdam, Netherlands, 1994; pp 1-60.

[3] Newton, L. E. Aloes in Habitat. In Aloes: The Genus Aloe, Reynolds, T., Ed. CRC Press: Boca Raton, Florida, 2004; pp 3-14.

[4] Kokwaro, J. O. Medicinal Plants of East Africa. $2^{\text {nd }}$ ed.; Kenya Literature Bureau: Nairobi, 1993.

[5] Mukonyi, K. W.; Owuor, B.; Chikamai, B. N.; Wabuyele, E. Status of Aloe exploitation, conservation and its distribution to communities' livelihoods in Kenyan drylands. J. Disc. Innov., 2007, 19, 231-241.

[6] Waihenya, R. K.; Mtambo, M. M.; Nkwengulila, G. Evaluation of the efficacy of the crude extract of Aloe secundiflora in chickens experimentally infected with Newcastle Disease Virus. $J$. Ethnopharma., 2002, 79 (3), 299-304.

[7] Waihenya, R. K.; Mtambo, M. M.; Nkwengulila, G.; Minga, U. M. Efficacy of crude extract of Aloe secundiflora against Salmonella gallinarum in experimentally infected free-range chickens in Tanzania J. Ethnopharma., 2002, 79 (3), 317-323.

[8] Waihenya, R. K.; Keriko, J. M.; Mtambo, M. M. A.; Nkwengulila, G.; Kayser, O.; Hafez, H. M. Antiviral activity of the crude extracts and phytochemical fractions of Aloe secundiflora against Newcastle Disease Virus. J. Trop. Microb. and Biotech., 2005, 1 (1), 4.

[9] Msoffe, P. L. M.; Mbilu, Z. M., The efficacy of crude extract of Aloe secundiflora on Candida albicans. Afr. J. Trad. Complem. Alter. Med., 2009, 6 (4), 592-595.

[10] Waihenya, R.; Kayser, O.; Hagels, H.; Zessin, K. H.; Mtambo, M.; Nkwengulila, G., The phytochemical profile and identification of main phenolic compounds from the leaf exudate of Aloe secundiflora by High-Performance Liquid Chromatography-Mass Spectroscopy. J. Phytochem. Anal., 2003, 14 (2), 83-86.

[11] King, E. G., Facilitative effects of Aloe secundiflora shrubs in degraded semi-arid rangelands in Kenya J. Arid Environ., 2008, 72 (4), 358-369.

[12] King, E. G.; Stanton, M. L. Facilitative effects of Aloe shrubs on grass establishment, growth, and reproduction in degraded Kenyan rangelands: Implications for restoration J. Rest. Ecol., 2008, 16 (3), 464-474.
[13] Newton, L. E. On the suitability of Kenyan Aloe for commercial cultivation E. Afr. Nat. Hist. Soc. Bull., 1987, 17, 5-8.

[14] Mukonyi, K. W.; Situma, C. A.; Lusweti, A.; Kyalo, S.; Erik, K. Commercial wild Aloe resource base in Kenyan and Ugandan drylands as alternative livelihoods source to rural communities. $J$. Disc. Innov., 2007, 19, 220-230.

[15] Lubia, I. K.; Kyalo, S. N.; Mukonyi, K. W.; Lusweti, A. M. Situma, C. A. Strategy for conservation and management of commercial Aloe species in Kenya wildlife services: Nairobi., 2008, 2-45.

[16] Ozturk, H. H. Experimental determination of energy and exergy efficiency of solar parabolic cooker. J. Solar. Energy, 2004, 77 (1), 67-71.

[17] Arenas, J. M. Design, development and testing of a portable parabolic solar kitchen. J. Renewable Energy, 2007, 32 (2), 257266.

[18] Schwarzer, K.; Vieira da Siva, M. E., Characterization and design of solar cookers. J. Solar. Energy, 2008, 82 (2), 157-163.

[19] Kaushik, S. C.; Gupta, M. K. Energy and exergy efficiency comparison of community-size and domestic-size paraboloid solar cooker performance. Energy. Sustain. Dev., 2008, XII (3), 60-64.

[20] Shuklaa, S. K. Comparison of energy and exergy efficiency of community and domestic type parabolic solar cookers. Int. J. Green Energy, 2009, 6 (5), 437-449.

[21] Karagiorgas, M.; Botzios, A.; Tsoutsos, T. Industrial solar thermal applications in Greece economic evaluation, quality requirements and case studies. J. Renew. Sustain. Energy Rev., 2001, 5 (2), 157173.

[22] Kalogirou, S. The potential of solar industrial process heat applications. J. Appl. Energy, 2003, 76 (4), 337-361.

[23] Waller, T. A.; Pelley, R. P.; Strickland, F. M. Industrial processing and quality control of Aloe Barbadensis (Aloe vera) gel. In Aloes: The Genus Aloe, Reynolds, T., Ed. CRC Press: London, 2004; pp 134-205.

[24] Ramachandra, C. T.; Rao, P. S. Processing of Aloe vera leaf gel: A review. Am. J. Agric. Biol. Sci., 2008, 3 (2), 502-510.

[25] ASTM D1895-96 (2010). Standard test method for apparent density, bulk factor and pourability of plastic materials.

[26] Chantal, O. Physical and chemical characteristics of Aloe gels. M.Sc. Thesis, University of Johannesburg, 2005.

[27] Funk, P. A. Testing and reporting solar cooker performance. In ASAE Standards, USDA, ARC., 2003; pp. 825-826.

[28] Thoruwa, T. F. N. Physical and microbiology investigations of day and night photovoltaic-desiccant solar crop dryer for village use in Kenya. University of Strathclyde, Glasgow, 1996.

[29] Zonta, F.; Masotti, P.; Bogoni, P. In Analysis by HPLC of aloin in Aloe and various products, Proceedings of the Conference, XVI National Conference of Commodity, September 1-3; Pavia, 1994; pp. 392-398.

[30] Zonta, F.; Bogoni, P.; Masotti, P.; Micali, G. High-performance liquid chromatographic profiles of Aloe constituents and determination of aloin in beverages, with reference to the EEC regulation for flavouring substances. J. Chromatogr. A 1995, 718 (1), 99-106.

[31] Schwarzer, K.; Vieira da Silva, M. E. Solar cooking system with or without heat storage for family and institutions. J. Solar Energy, 2004, 75 (1), 35-41.

[32] Nandwani, S. S. Solar cookers-cheap technology with high ecological benefits. J. Ecol. Econ., 1996, 17, 73-81.

[33] Reynolds, T. Aloe Chemistry. In Aloes: The Genus Aloe, Reynolds, T., Ed. CRC Press: Boca Raton, London, New York, Washington, D.C, 2004; pp 39-74.

[34] Groom, Q. J.; Reynolds, T. Barbaloin in Aloe species. J. Planta Med., 1987, 53 (4), 345-348.

[35] Ishii, Y.; Tanizawa, H.; Takino, Y. Fluorophotometry of barbaloin Aloe. Chem. Pharm. Bull., 1984, 32, 4946-4950.

Received: May 29, 2011
(c) Ondiaka et al.; Licensee Bentham Open.

Revised: July 12, 2011

Accepted: July 19, 2011

This is an open access article licensed under the terms of the Creative Commons Attribution Non-Commercial License (http://creativecommons.org/licenses/by-nc/3.0/) which permits unrestricted, non-commercial use, distribution and reproduction in any medium, provided the work is properly cited. 